\title{
Development Of Processed Rinuak Fish (Psilopsis Sp) To Improve Nutritional Quality Of Toddler Of Stunting
}

\author{
Yuliana ${ }^{1}$, Linda Rosalina ${ }^{2}$, Ade Iferamuna ${ }^{3}$, Afifah Nur Hasanah \\ Faculty of Tourism and Hospitality, Padang State University,West Sumatra, Indonesia \\ yuliana@fpp.unp.ac.id
}

\begin{abstract}
Stunting is one of the problems of a lack of protein intake that occurs for a long time to interfere with growth. Increasing the quality of nutrition based on local food that has the potential to be one solution, including raw fish rinuak which is rich in protein. This study aims to analyze the needs and identify the potential of rinuak fish as a local food ingredient and to design standardized products to improve the nutritional quality of children under five with stunting. The survey method was used to collect data with qualitative and quantitative approaches using the Participatory Action Research (PAR) design. Furthermore, the standardization of recipes for processed rinuak fish was carried out by eight expert validators in the fields of food, food, and nutrition. The results showed that the potential for rinuak fish in Lake Maninjau in the last two years is abundant. Standardized processed rinuak fish, namely nuggets, jerky, and shredded rinuak can be used as an alternative food for toddlers.
\end{abstract}

Keywords - Rinuak Fish, Nutritional Quality, Toddler, Stunting

This work is licensed under a Creative Commons Attribution-ShareAlike 4.0 International License.

\section{INTRODUCTION}

Stunting is a description of the occurrence of barriers to growth, which is caused by a lack of nutritional intake for a long time (Loya, 2017: 84). Stunting occurs starting in the womb in the form of a fetus until the age of 5 years. Stunting can be seen from the height that is not suitable for age (Kementrian Kesehatan RI, 2018). Laurus et al (2016: 364) that, "a child's optimal growth can be indicated by many factors, among them is body height".
Results of Monitoring Nutritional Status (PSG, 2015: 3) the prevalence of stunting under five in Indonesia is $29 \%$, an increase in 2017 to $29.6 \%$, without exception West Sumatra Province. West Sumatra, namely in East Pasaman Regency, found 15,025 and West Pasaman as many as 23,435 children under five suffer from stunting (Kementrian Kesehatan, 2015). 


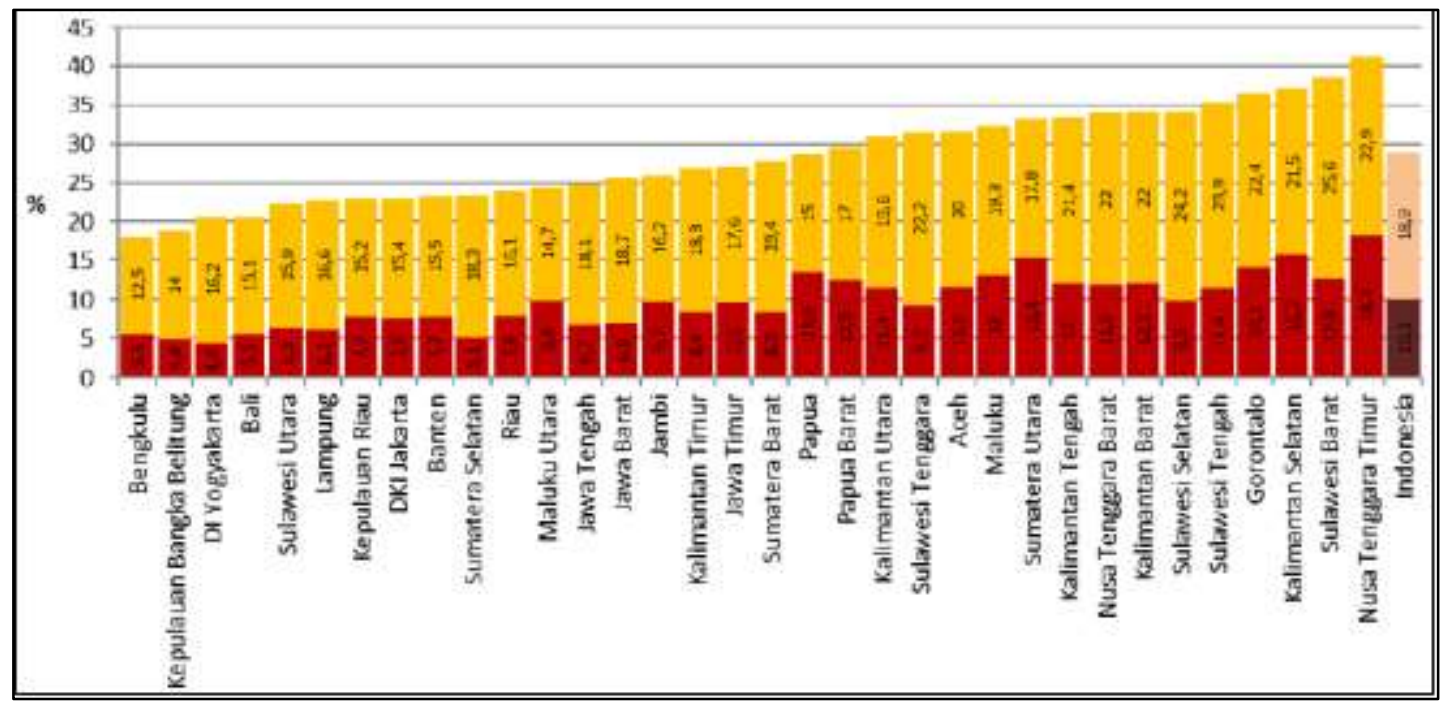

Figure 1.Percentage of Short Toddler in Indonesia in 2015

Source: PSG 2015, Ministry of Health RI (2015)

Efforts to improve the nutritional quality of the safest food are based on local food, namely by utilizing rinuak fish (psilopsis sp) whose production is abundant every day in Lake Maninjau, Agam Regency, West Sumatra. Efforts to accelerate the reduction of stunting in children under five are through improving the quality of nutrition and food security at the household level (Yuliana, Katin and Holinesti, 2010).

At the end of 2016 to mid-2018, the rinuak fish were threatened with extinction, but by the end of 2018 until now, the catch of rinuak fish in Lake Maninjau was again abundant (Yuliana, et al. 2018). The rinuak fish

\section{RESEARCH METHODS}

Data was collected using qualitative and quantitative approaches using the Participatory Action Research (PAR) design. Researchers and related stakeholders collect data together by conducting field observations, distributing questionnaires and interviews, and taking documentation. The analysis conducted was an analysis of the needs and potential of local raw material for rinuak fish which could improve the nutritional quality of children under five with stunting.

\section{RESULTS AND DISCUSSION}

\section{a. Potential of Rinuak Fish}

Based on the results of interviews conducted with the Maninjau community, in this case, the fishermen who caught the rinuak, the head of the rinuak fish processing UKM and local regional leaders such as the secretary of the Tanjung Raya subdistrict head, Wali Nagari Maninjau, Wali Jorong, and other community leaders, were obtained information on the potential of has a small body posture due to the size of $2-3 \mathrm{~cm}$. Dry rinuak fish contains $20.72 \%$ protein and $5.76 \%$ fat (Sihombing, Togun., 2013).

So far, rinuak fish is only consumed by the public in the form of frying, steaming, and chopping. However, what the community, especially parents of children under five, need to do is adjusting standardized recipes and developing traditional Minang foods that have been enriched with nutritional content. In this research, rinuak fish processing based on the preferences of children under five in general, namely rinuak fish will be processed in the form of nuggets, dendeng, and abon.

The product validity test is a response statement that symbolizes the amount, level of intensity, after the panelist senses. Each panelist conducts tests and assessments of the product and writes down his response. Organoleptic analysis of shape, aroma, texture, color, and taste was carried out utilizing a level test with a score of 1-5. The higher the value the better the product quality. The number involved 8 expert panelists. The test was carried out at $9.00-11.00$ or 14.00 - 16.00 WIB where the panelists were not hungry and not full.

rinuak fish. in Lake Maninjau in the last two years with abundant production. From the 47 UKM groups interviewed, it can be seen that the average rinuak processed is $3 \mathrm{~kg}$ per day on weekdays (MondaySaturday). There was an increase in holidays (weeks) to an average of $5 \mathrm{~kg}$ per day. During holidays or school holidays, the average of rinuak fish processed by UKM is up to $15 \mathrm{~kg} /$ day. 
Supporting factors, such as clean water conditions and a friendly natural environment, support the production of rinuak fish. Besides that, the awareness of the local community to keep lake water clean is also very much needed. This can be done by limiting the number of karamba businesses in Lake Maninjau because the leftovers of the karamba fish can contaminate the lake.

b. Standard Recipe for Rinuak Fish Processed

1) Nugget Rinuak

So far, the popular nuggets are meatbased. Fish nuggets are not much different from other nuggets in terms of seasoning, which differ only in the raw material for making nuggets. Kim, Hack-Youn et al. (2015: 19), Most nuggets cook rapidly and develop a golden color, crisp texture, and good flavor at frying temperatures between 160 and $190^{\circ} \mathrm{C}$. This also agrees with Permadi, S.N, et al (2012: 115) which states that nuggets are a form of processed meat or animal protein products that are ground and seasoned, then covered with flour gluten, greasing the bread (breading), and frying. half cooked and then frozen to maintain the quality during storage.

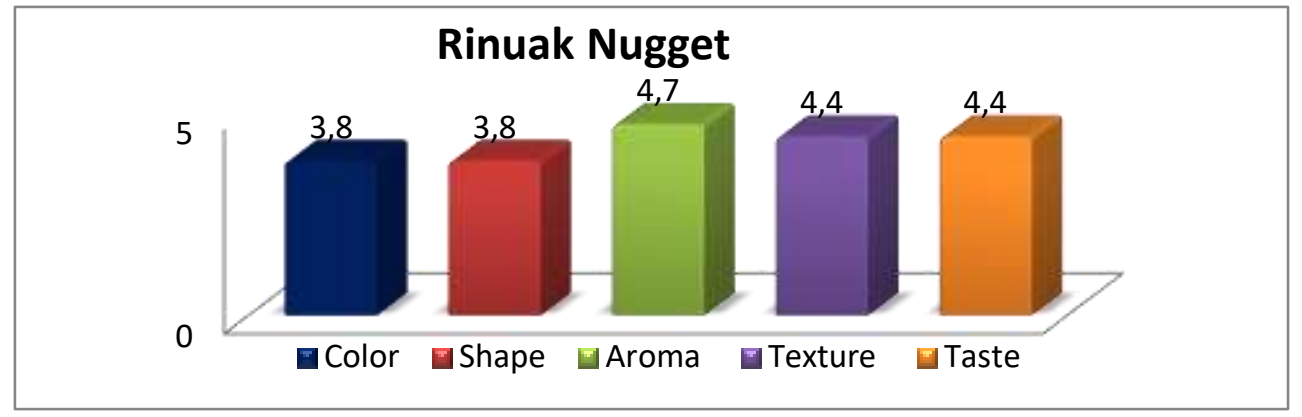

Figure 2. Product Quality Results of Nugget Rinuak

From the results of the rinuak nugget test by the validator, several conclusions were obtained, namely:

a) The color quality with an average score of 3.8 was categorized quite good, golden brown, but it would be better if the color was a little lighter so that the nuggets would be more attractive. Khatimah, Nurul, et al (2018: 64) in their research stated that the non-enzymatic reactions that occur have a direct impact on the color of the nuggets produced, the color caused by the reaction between sugars and amino acids known as the maillard reaction. So that the product color is slightly brown.

b) The quality of the shape with an average score of 3.8 is recommended for the shape of the stick and its size to be slightly reduced. The longer the stirring time when adding the carrots will cause the water

2) Dendeng Rinuak (Jerky of Rinuak)

Dendeng is a traditional way of preserving meat that is well known by Indonesians, contained in the carrots to come out, so that the dough becomes soft (Firdaus, et al. 2014).

c) The aroma quality with an average score of 4.7 categories is good. Nisa, Tisnginiyati Khairun (2013: 68) revealed that the aroma of nuggets is also formed during the steaming and frying process.

d) Texture quality with an average score of 4.4 in good categories, soft and savory texture. This agrees with Wulandari, Eka, et al., (2016: 97), the higher the water holding capacity, the softer the nuggets are produced..

e) Taste quality with an average score of 4.4 in the tasty and delicious categories. Wulandari, Eka, et al., (2016: 97) agree that spices play an important role in the formation of nuggets..

especially the Minangkabau. Currently, jerky is not only made from beef, but has been made with other basic ingredients such as tuna, catfish, or goldfish.. 


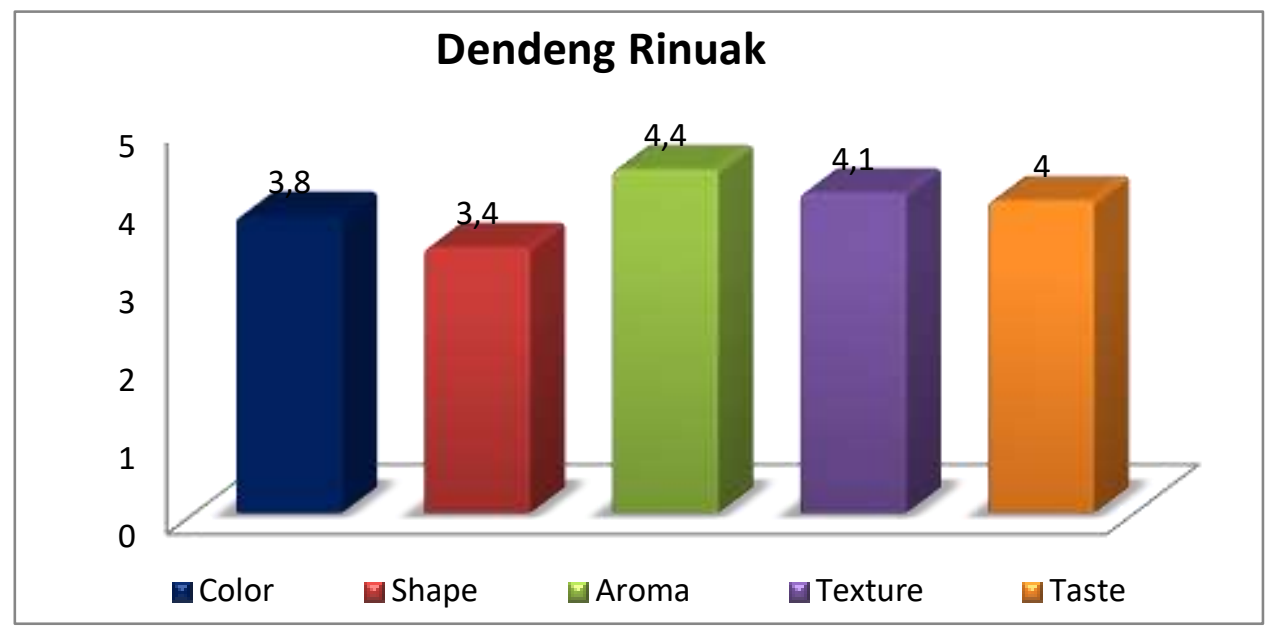

Figure 3. Product Quality Results of Dendeng Rinuak

In this study, dendeng was processed from rinuak fish. The recipe used in making rinuak jerky is no different from beef dendeng. However, in this study only using natural ingredients, there is no use of additional ingredients like other flavoring ingredients.

From the results of the dendeng rinuak test by the validator, several conclusions were obtained, namely:

a) The color quality with an average score of 3.8 in the color category is good. Jamhari et al. (2005) stated that the color of dendeng can be affected by the temperature used in the drying process.

b) The quality of the shape with an average score of 3.4 is quite good, it is advisable to make it thin again.

c) The aroma quality with an average score of 4.4 is good and it attracts interest. According to Ikhsan, Muh. Et al (2016: 120 ), that this is thought to be due to the aroma of fish dendeng that is produced using distinctive flavorful spices such as

3) Abon Rinuak (Shredded Rinuak)

Shredded is food that is usually made from animal meat fiber. Their appearance is usually light brown to blackish in color. Shredded looks like cotton fibers, because it is dominated by the aroma of coriander, and each treatment uses the same spices. The process of forming the aroma occurs when the ingredients are mixed until they become spices and will last until the drying process so that the distinctive aroma of jerky is formed (Henny Krissetiana, 2003).

d) The texture quality with an average score of 4.1 in the jerky texture category is appropriate. In line with Dadik's research (2006), it is said that the lower the water content in dendeng as the temperature increases, the crunchier the dendeng product is.

e) Taste quality with an average score of 4 categories tasty and delicious. Based on Ikhsan's research, Muh. Et al (2016: 120), that the drying temperature and the amount of water content can affect the level of fish dendeng produced.

dried muscle fibers that are shredded. Because it is dry and has almost no residual moisture content, shredded is usually stored for weeks to months in airtight packaging (Wikipedia, 2019) 


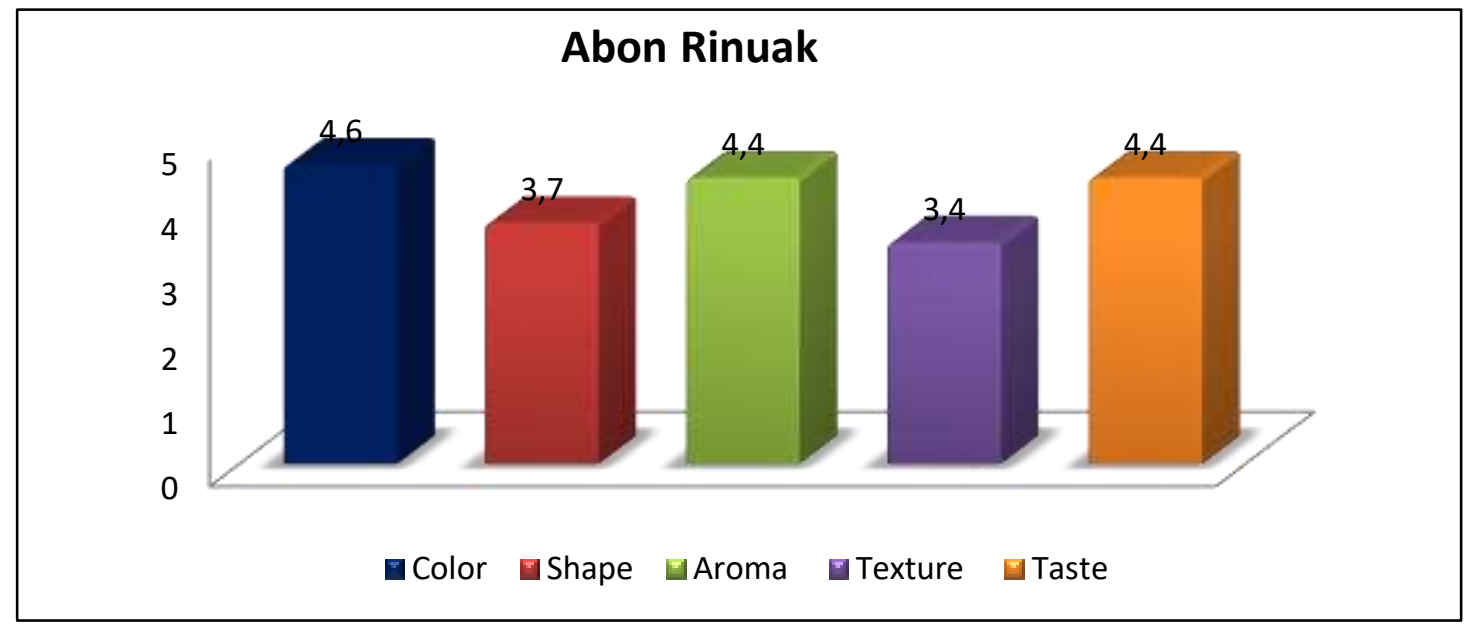

Figure 4. Quality Results of Abon Rinuak Products

From the results of the abon rinuak test by the validator, several conclusions were obtained, namely:

a) The color quality with an average score of 4.6 is categorized as good. According to Mustar's (2013) research, this is due to the frying process a color change as a result of the reaction of amino acids and reducing sugars, resulting in a brownish yellow color during the frying process.

b) The quality of the shape with an average score of 3.7 is categorized as resembling abon in general, but it is recommended that it is slightly smaller so it can be consumed by toddlers.

c) The aroma quality with an average score of 4.4 is good and it attracts interest. According to the research of Mustar (2013), in the frying process, there is a

\section{CONCLUSION}

The results showed that the potential for rinuak fish in Lake Maninjau in the last two years is abundant. The need for processed rinuak fish products is very high, considering that so far processing has only been limited by frying, milling, grouting, or making rinuak change in certain compounds in the oil and a caramelization process occurs in several sugar compounds which will cause a distinctive aroma.

d) Texture quality with an average score of 3,4 is good, but dries better. In the research of Huthaimah, et al. (2017: 251) revealed that this is presumably because the texture of the abon using the roasting method tends to be more crispy than the frying method.

e) Taste quality with an average score of 4.4 in the tasty and delicious categories. According to Mustar (2013), at the frying stage, there will be the absorption of oil into the ingredients, where the oil contains high fat so that it produces a savory taste in abon.

peanut brittle. There is still a limited number of people who process rinuak fish into rinuak nuggets, rinuak dendeng, and rinuak abon. The resulting standard recipe design is a recipe for processing rinuak fish into rinuak nuggets, rinuak dendeng, and rinuak abon which can be alternative foods for stunting toddlers. 


\section{REFERENCE}

Dadik. 2006. Pengaruh Waktu Curing (Perendaman Dalam Larutan Bumbu) Terhadap Mutu Dendeng Fillet Ikan Lele Dumbo (Clarias Gariepinus) Selama Penyimpanan. Skripsi tidak diterbitkan. Bogor: Departemen IImu dan Teknologi Pangan, Fakultas Teknologi. Pertanian, Institut Pertanian Bogor

Firdaus. Anni Faridah, dan Rahmi Holinesti. 2014. Pengaruh Penambahan Wortel Dan Rumput Laut Terhadap Kualitas Nugget Tempe. E-Journal Home Economic and Tourism Vol 7, No 3 (2014).

Huthaimah, et al. 2017. Pengaruh Jenis Ikan Dan Metode Pembuatan Abon Ikan, Terhadap Karakteristik Mutu dan Tingkat Penerimaan Konsumen. Jurnal IImiah Mahasiswa Pertanian Unsyiah, Vol. 2, No. 3, Agustus 2017: 244-254

Ikhsan, Muh. Et al. 2016. Pengaruh Variasi Suhu Pengering Terhadap Mutu Dendeng Ikan Lele Dumbo (Clarias Gariepinus). Jurnal Pendidikan Teknologi Pertanian, Vol. 2 (2016) : 114-122

Jamhari, E. Suryanto, dan Soeparno. 2005. Karakteristik organoleptik dendeng dari daging kambing bligon yang diberi pakan daun pepaya (carica papaya) berbagai level. Buletin peternakan 29 (3) 115-121

Kementrian Kesehatan RI. 2015. Pedoman Gizi Seimbang. Kementrian Kesehatn RI

Khatimah, Nurul. Kadirman, dan Ratnawaty Fadilah. (2018). Studi Pembuatan Nugget Berbahan Dasar Tahu Dengan Tambahan Sayuran. Jurnal Pendidikan Teknologi Pertanian Volume 4 September Suplemen (2018) : S59- S68.

Kim, Hack-Youn. et al. 2015. Quality Evaluation of Chicken Nugget Formulated with Various Contents of Chicken Skin and Wheat Fiber Mixture. Korean J. Food Sci. An. Vol. 35, No. 1, pp. 19 26 (2015).

Laurus, Geraldo, dkk. 2016. Pattern of Energy \& Protein Intake Among Stunted Children Aged 3-5 Years In Jatinangor. Althea Medical Journal Page 364. Bandung

Loya, Risani Rambu Podu, Nuryanto. 2017. Pola Asuh Pemberian Makanan Pada Balita Stunting Usia 6-12 Bulan Di Kabupaten Sumba Tengah Nusa Tenggara Timur. Journal of Nutrition College Volume 6 No. 1. Pp 8395

Mustar. 2013. Studi pembuatan Abon Ikan Gabus (Ophiocephalus Striatus) Sebagai Makanan Suplemen (Food Suplement). Makassar. Teknologi pertanian Universitas Hasanuddin

Nisa, Tisnginiyati Khairun. 2013. Pengaruh Substitusi Nangka Muda (Artocarpus Heterophyllus Lmk) Terhadap Kualitas Organoleptik Nugget Ayam. Food Science and Culinary Education Journal 2 (1) (2013) p. 63-71.

Permadi, S.N. S Mulyani, dan A Hintono. 2012. Kadar Serat, Sifat Organoleptik, dan Rendemen Nugget Ayam yang Disubstitusi dengan Jamur Tiram Putih (Plerotus Ostreatus). Jurnal Aplikasi Teknologi Pangan Vol. 1 No. 4 p. $115-120$.

Wulandari, Eka, et al. 2016. Karakteristik Fisik, Kimia dan Nilai Kesukaan Nugget Ayam Dengan Penambahan Pasta Tomat. Jurnal IImu Ternak, Desember 2016, Vol.16, No.2 p. 95-99.

Yuliana, Y.E. Katin dan R. Holinesti. 2010. Upaya Keluarga dalam Mewujudkan Ketahanan Pangan dan Status Gizi Baik bagi Balita di Sumatera Barat. Jurnal Pendidikan dan Keluarga, Jurusan Kesejehteraan Keluarga Fakultas Teknik Universitas Negeri padang, Volume 2, Nomor 5, Agustus 2010, Padang. 